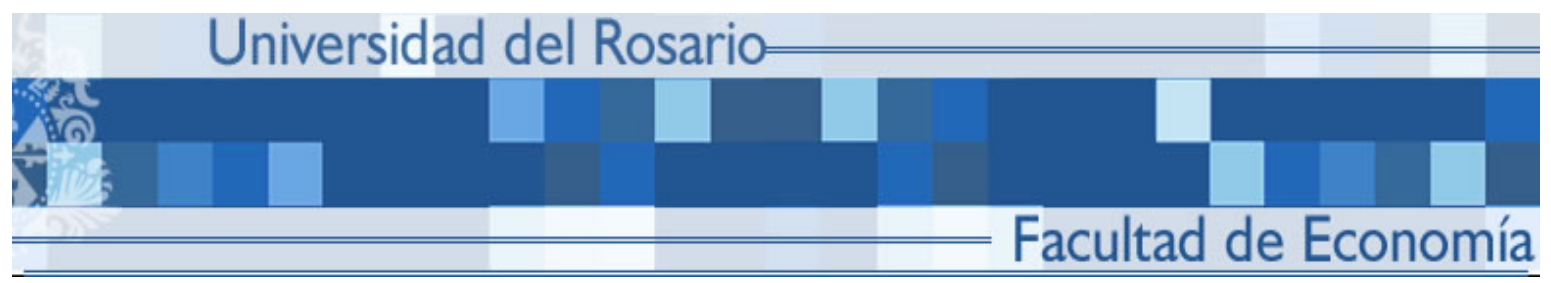

A SIMPLE TEST OF MOMENTUM IN FOREIGN EXCHANGE MARKETS

Andrés Felipe García-Suaza

José E. Gómez González 


\title{
A Simple Test of Momentum in Foreign Exchange Markets ${ }^{1}$
}

\author{
Andrés Felipe García-Suaza $\quad$ José E. Gómez González ${ }^{3}$
}

March 14, 2011

\footnotetext{
${ }^{1}$ Disclaimer: The findings, recommendations, interpretations and conclusions expressed in this paper are those of the authors and not necessarily reflect the view of the the Banco de la Republica or its Board of Directors, or the Department of Economics of the Universidad del Rosario.

${ }^{2}$ Assistant Professor, Economics Department, Universidad del Rosario. Calle 14 \# 4-69, Bogotá, Colombia. E-mail address: andres.garcia@urosario.edu.co

${ }^{3}$ Senior Research Economist, Banco de la República (Central Bank of Colombia). Carrera 7 \# 14-78 Piso 11, Bogotá, Colombia. E-mail address: jgomezgo@banrep.gov.co
} 


\begin{abstract}
This study proposes a new method for testing for the presence of momentum in nominal exchange rates, using a probabilistic approach. We illustrate our methodology estimating a binary response model using information on local currency / US dollar exchange rates of eight emerging economies. After controlling for important variables affecting the behavior of exchange rates in the short-run, we show evidence of exchange rate inertia; in other words, we find that exchange rate momentum is a common feature in this group of emerging economies, and thus foreign exchange traders participating in these markets are able to make excess returns by following technical analysis strategies. We find that the presence of momentum is asymmetric, being stronger in moments of currency depreciation than of appreciation. This behavior may be associated with central bank intervention.
\end{abstract}

JEL Classification: $614 ; G 15 ; C 41$

Keywords: Momentum; foreign exchange markets; hazard duration analysis; emerging economies. 


\section{Introduction}

The existence of momentum in spot exchange rates - and more generally in the short-term returns of financial assets - has been well established in the academic literature. While studying the hypothesis of foreign exchange markets efficiency, researchers have found that nominal exchange rates display behaviors akin to mean reversion and positive serial correlation (see, for instance, Levich (1989) and Taylor (1992)). Traders in the foreign exchange (fx herein) markets have widely exploited trading strategies that combine mean reversion and momentum ${ }^{1}$, such as moving average rules, to generate excess returns over a buy-and-hold strategy ${ }^{2}$. As documented by Taylor and Allen (1992), in the short-run traders are more likely to follow strategies based on technical analysis than to base their actions on the behavior of economic fundamentals. In fx markets, strategies based on technical indicators are more likely to succeed because, as Meese and Rogoff (1983) show, while macroeconomic fundamentals have explanatory power for stock returns, they do not have it for nominal exchange rates. Additionally, economic fundamentals usually have a lower frequency of fluctuation than nominal exchange rates.

In order to have technical trading strategies that generate positive risk-adjusted returns in fx markets, it must be the case that these markets are not fully efficient. If fx markets were totally efficient, currencies should fluctuate randomly after controlling for the relevant information set at all moments in time. However, there is vast evidence that shows that the random walk hypothesis does not prevail in fx markets (see, for example, LeBaron (1999) and Marsh (2000)). In other words, there is ample empirical evidence showing that currency price changes represent more than random departures from previous prices, and therefore short-run exchange rate movements are at least partially predictable. There might be multiple sources for market inefficiencies in exchange $\mathrm{fx}$ markets. However, the academic literature has identified two main sources: noise trading and central bank intervention (Okunev and White (2003)). The former states that noise traders, who make decisions based on the previous movements of the currencies, dominate

\footnotetext{
${ }^{1}$ Chiang and Jiang (1995) find that foreign exchange returns exhibit high positive correlations in the short-run (momentum) and negative correlations in the long-run (mean revertion).

${ }^{2}$ Many studies have shown that simple moving average trading rules systematically beat a buy-and-hold trading strategy. See, for example, Jegadeesh and Tirman (2001), Okunev and White (2003), and Balvers and Wu (2006).
} 
fx markets. The latter posits that central banks, not interested in trading profits, intervene fx markets to dampen foreign exchange volatility and to ensure that currencies reflect their targeted values. Central bank intervention can thus generate non-random exchange rate movements, and can even foster profitable trading strategies which can be exploited by fx traders (Sweeny (1986) and Neely (1997)). Regardless of the source of market inefficiencies, economists and researchers in the field of behavioral finance have shown that exchange rate and, more generally, stock momentum is consistent with psychological feedback mechanisms. When market participants observe a currency depreciating (appreciating) they assume it is more likely it will continue to depreciate (appreciate) in the short-run, and will therefore enter into the market in a kind of "bandwagon effect" (Malkiel (2003)). Various studies have formally tested for the presence of momentum in exchange rates. Most tests employ the framework developed by Fama and French (1998), and examine sample autocorrelations of realized exchange rate returns to check whether or not the series present positive serial correlation. If return correlations are statistically equal to zero, then it is said that exchange rates follow a random walk process. In particular, a zero autocorrelation of exchange rate returns indicates that market participants respond only to news which, by definition, are unpredictable. Most of the tests estimate correlations in currency returns over different time horizons, employing the generalized method of moments (GMM) estimator to calculate the variance-covariance matrix with correction for serial correlation (see, for instance, Chiang and Jiang (1995)).

This study proposes a new method for testing for the presence of momentum in nominal exchange rates, using a probabilistic approach. We estimate a logit model using information on local currency / US dollar exchange rates of eight emerging economies ${ }^{3}$. After controlling for important variables affecting the behavior of exchange rates in the short-run, we show evidence of exchange rate inertia; in other words, we find that exchange rate momentum is a common feature in this group of emerging economies, and thus fx traders participating in these markets are able to make excess returns by following technical analysis strategies. We find that the presence of momentum is asymmetric. It is stronger during periods of exchange rate depreciation than during periods of exchange rate appreciation. This empirical regularity may obey to the "fear of floating" in emerging economies identified by Calvo and Reinhart (2002), which has shown to be

\footnotetext{
${ }^{3}$ Colombia, Peru, Brasil, Chile, Mexico, Turkey, Hong Kong, and South Africa.
} 
asymmetric in periods of local currency appreciation and depreciation. In fact, as Levy-Yeyati and Sturzenegger (2007), and Pontines and Rajan (2010) show, emerging market economies are more sensitive to exchange rate appreciation than depreciation and therefore central bank authorities in these economies are more likely to intervene fx markets trying to depreciate their currencies. The method proposed in this study allows to test for the exchange rate momentum hypothesis in a very simple way, which has not been proposed before in the academic literature. While existing studies of momentum follow a time-series approach estimating the autocorrelation function and performing variance-ratio tests to contrast the white noise hypothesis on exchange rate returns, our methodology estimates the probability that exchange rate presents short-term memory. Our methodology has some advantages over the existing one, and its able to answer to interesting questions that cannot be answered when looking at sample autocorrelation functions.

When autocorrelation functions are analyzed, researchers have to assume particular parametric forms for volatility clusters. Therefore, test results are sensitive to the chosen parametric forms. It is not uncommon that results are not robust under different model specifications (see, for instance, Michello and Chowdhury (2009), and Pavlova and Parhizgari (2008)). The probabilistic approach for testing momentum proposed in this study is based on duration hazard analysis, and provides a very flexible framework which overcomes the problem of assuming a particular parametric form for volatility clusters. Our approach presents other advantages, including the maximal use of existing data and the identification of the likelihood of effects at various exposure levels.

The model proposed here is able to provide answers to relevant questions such as: conditional on having observed an appreciation (depreciation) of today's exchange rate, what is the probability that tomorrow's exchange rate will continue to appreciate (depreciate) given the behavior of the economic fundamentals? Or, how do central bank interventions affect the probability that the exchange rate continues to appreciate (depreciate) given the value of the control variables?

The next section are organized as follows: section 2 presents a brief data description, section 3 describes the empirical strategy and estimation results; and finally, section 4 presents the concluding remarks. 


\section{Description of the data}

In this paper we study the existence of exchange rate momentum in a sample of eight emerging economies. One of the main sources of momentum in fx markets identified in the literature is central bank intervention (see, for instance, Okunev and White (2003), and Beine et al. (2006)). Recent studies have shown that central bank intervention is more effective in emerging market economies (Canales-Kriljenko (2003)). We chose these particular list of eight countries due to three main reasons: i). there are particular case studies of the effects of central bank intervention in fx markets for these countries (Tapia and Tokman (2004) for Chile; Guimaraes and Karacadag (2004) for Mexico and Turkey; Domac and Mendoza (2004) for Turkey; Neely (2001) for Brazil, Chile, Hong Kong, and Mexico; Echavarría et al. (2009) for Colombia; in addition, internal studies on the effectiveness of exchange rate intervention have been developed for Peru and South Africa); ii). there is information on CDS and stock market indices for all of these countries since the beginning of the 2000s; and, iii). all of these countries follow similar exchange rate regimes, labeled as "managed floating" by Reinhart and Rogoff (2004).

Figure 1 shows the time-series behavior in daily frequency of the exchange rates of the countries included in our sample, from January 2001 to December 2010. The first panel shows exchange rates for South American countries while the second panel shows exchange rates for the other emerging market economies. Note that all South American countries exhibit a persistent process of local currency appreciation during the sample period, with a temporal tendency break-down around September 2008 as a consequence of the international financial crisis. 
Figure 1:Exchange rates in the eight emerging economies

South American economies
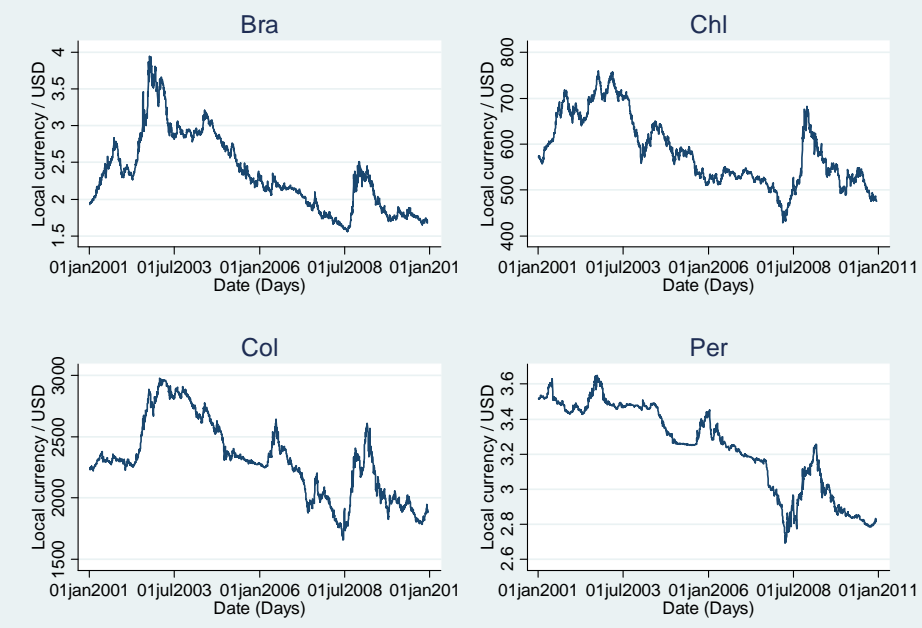

Figure 1:Exchange rates in the eight emerging economies Other emerging economies
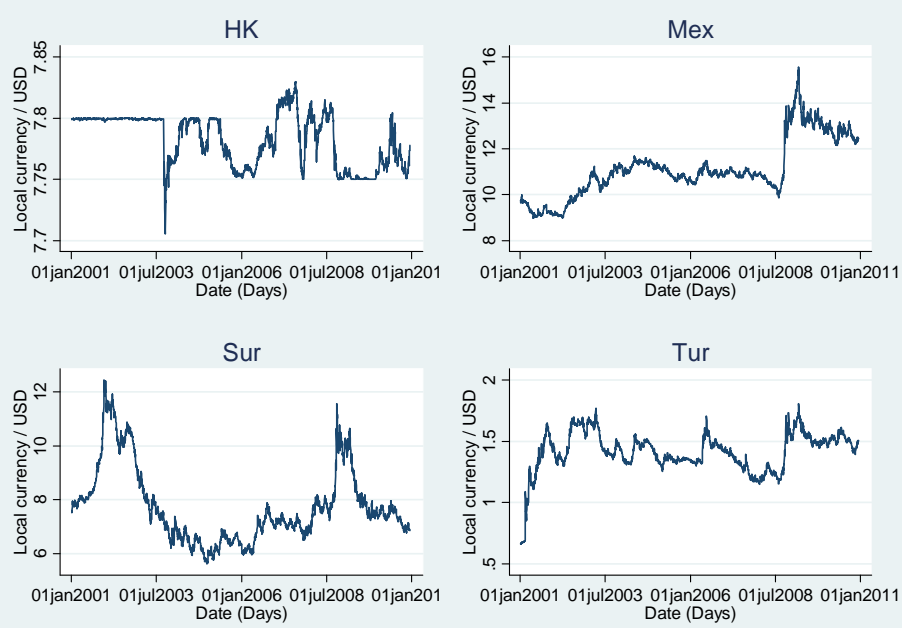

In this study we test for exchange rate momentum. We check whether the probability of obtaining a positive (negative) exchange rate return is higher when it was positive (negative) in the preceding period. For this purpose we collect information on daily end-of-the-day exchange rates for the eight market economies considered, as well as daily data on important control variables such as stock market 
indices, CDS and VIX. Control variables are included to isolate momentum from common movements of exchange rates with these variables. Table 1 presents descriptive statistics of these variables by country. All sample means of exchange rate returns are negative as expected, except for Hong Kong, while larger return dispersions correspond to South Africa, Brazil, and Turkey. Note that unconditionally the empirical probability of observing an increase in the exchange rate return is higher than observing a decrease for all countries except for Hong Kong.

Table 1: Descriptive statistics

\begin{tabular}{lccccc}
\hline \multirow{2}{*}{ Country } & \multicolumn{5}{c}{ Exchange rate returns } \\
\cline { 2 - 6 } & Mean & 25th pctile & 75th pctile & Std. Error & $\begin{array}{c}\text { Proportion of } \\
\text { decreases in returns }\end{array}$ \\
\hline Brazil & -0.00017 & -0.00507 & 0.00440 & 0.00015 & 52.35 \\
Chile & -0.00013 & -0.00323 & 0.00293 & 0.00009 & 51.30 \\
Colombia & -0.00010 & -0.00250 & 0.00228 & 0.00009 & 51.17 \\
Hong Kong & 0.00001 & -0.00006 & 0.00008 & 0.00000 & 49.00 \\
Mexico & -0.00002 & -0.00284 & 0.00254 & 0.00008 & 51.76 \\
Peru & -0.00009 & -0.00076 & 0.00060 & 0.00003 & 52.60 \\
South Africa & -0.00028 & -0.00592 & 0.00520 & 0.00017 & 52.17 \\
Turkey & -0.00015 & -0.00472 & 0.00382 & 0.00014 & 53.15 \\
\hline
\end{tabular}

\begin{tabular}{|c|c|c|c|c|}
\hline \multirow{2}{*}{ Country } & \multicolumn{4}{|c|}{ Stock market index returns } \\
\hline & Mean & 25th pctile & 75th pctile & Std. Error \\
\hline Brazil & 0.00055 & -0.00920 & 0.01146 & 0.00038 \\
\hline Chile & 0.00059 & -0.00446 & 0.00607 & 0.00020 \\
\hline Colombia & 0.00113 & -0.00437 & 0.00763 & 0.00029 \\
\hline Hong Kong & 0.00020 & -0.00641 & 0.00766 & 0.00035 \\
\hline Mexico & 0.00072 & -0.00586 & 0.00779 & 0.00027 \\
\hline Peru & 0.00120 & -0.00485 & 0.00752 & 0.00031 \\
\hline South Africa & 0.00054 & -0.00654 & 0.00789 & 0.00026 \\
\hline Turkey & 0.00070 & -0.01006 & 0.01234 & 0.00042 \\
\hline \multirow{2}{*}{ Country } & \multicolumn{4}{|c|}{ CDS } \\
\hline & Mean & 25th pctile & 75th pctile & Std. Error \\
\hline Brazil & 517.395 & 123.300 & 621.170 & 14.263 \\
\hline Chile & 65.647 & 21.333 & 81.995 & 1.272 \\
\hline Colombia & 264.436 & 136.575 & 389.733 & 3.665 \\
\hline Hong Kong & 21.430 & 10.250 & 40.771 & 0.526 \\
\hline Mexico & 145.400 & 78.313 & 176.250 & 1.929 \\
\hline Peru & 196.619 & 119.749 & 256.434 & 2.640 \\
\hline South Africa & 142.264 & 61.816 & 189.167 & 1.802 \\
\hline Turkey & 422.886 & 188.743 & 619.795 & 6.003 \\
\hline
\end{tabular}




\section{Empirical strategy and results}

The objective of this study is to provide a simple empirical test for the hypothesis of exchange rate momentum. Our approach consists in estimating a probabilistic model in which the dependent variable represents the probability that the sign of the exchange rate return in the current period is the negative of the sign of last period's exchange rate return.

We propose the following statistical framework. Consider two possible states of the world: $S_{t}=\{u, d\}, \forall t$ (intuitively, obtaining a positive return (up) and obtaining a negative return (down), respectively) where $S_{t}$ represents the state at time $t$. The current state is $u$ if the current exchange rate's return is positive, and it is $d$ when the current exchange rate's return is negative. Let $Y_{i j, t}$ be the probability of changing from state $i$ at time $t-1$ to state $j$ at time $t$, i.e.,

$$
Y_{i j, t}=\operatorname{Pr}\left(S_{t}=j \mid S_{t-1}=i\right)
$$

where $i, j=\{u, d\}$.

In order to test the hypothesis of momentum, we introduce covariates by defining the following function ${ }^{4}$ :

$$
Y_{i j, t}=\operatorname{Pr}\left(S_{t}=j \mid S_{t-1}=i, X_{t}, z_{t}, \beta\right)=I_{i, t} F\left(X_{t}, z_{t}, \beta\right)
$$

where $I_{i, t}$ represents an indicator function, $X_{t}$ is a vector of covariates at time $t$, $z_{t}$ is a dummy variable that takes the value of 1 if the exchange rate return's sign of the last period is different of the one of the current period, $\beta$ is a vector of parameters, and $F(\cdot)$ is a cumulative density function (cdf). The indicator function is specified in three different ways. In the first specification the indicator function takes on the value of 1 always. In the other two the indicator function is used to separate the cases in which the current returns of the exchange rate are positive or negative. We establish the last two specifications to test whether momentum acts asymmetrically depending on whether observed returns are positive or negative.

Our interest lies in the sign and significance of the parameter associated with $z_{t}$. If the sign of this parameter is negative and statistically significant it is possi-

\footnotetext{
${ }^{4}$ Using this framework we are able to estimate a transition matrix, following the methodology proposed by Gómez-González et al. (2009), and Gómez-González and Hinojosa (2010).
} 
ble to argue that exchange rate exhibits short term persistence or momentum. In other words, the probability of observing a positive (negative) exchange rate return today is higher if yesterday's return was also positive (negative).

The $X_{t}$ vector includes control variables such as Credit Default Swaps (CDS), stock market indices, and the Standard and Poor's VIX, all of these in daily frequency. These covariates allow us to control for issues such as risk aversion and temporal changes in assets ' value. It is possible to think that a variable like the stock market index might be determined at the same time of the dependent variable. In order to avoid the possible problem of simultaneity, we instrument this variable by lagging it one period and taking first differences. Additionally, we looked at pairwise correlations between covariates and found that the sample correlation between CDS and stock market indices was very high for all the countries included in the sample. Thus, we decided to exclude CDS from the estimations to reduce the probability of having multicollinearity issues ${ }^{5}$.

In this framework, the function $F(\cdot)$ can be any cumulative density function. In our case we chose the logistic $\operatorname{cdf}^{6}$. Recognizing that providing evidence for just one country, or for a list of countries by separate could lead us to weak evidence of momentum, we pooled the observations of the eight emerging countries ${ }^{7}$ in a data set and defined seven country dummies, setting Brazil as the base category. In all our specifications we use a linear index function, i.e. $F\left(X_{c, t}, z_{c, t}, \beta\right)=$ $\Lambda\left(\beta_{0}+\beta_{1} z_{c, t}+\beta_{2} V I X_{t}+\beta_{3} S T O C K_{c, t}+\sum_{c=1}^{7} \delta_{c} I_{c}\right)$, where $\Lambda$ represents the logistic cdf, $c$ indexes the country, STOCK $K_{c, t}$ holds for the stock market index of country $c$ at time $t, I_{c}$ is an indicator function taking the value 1 for country $c$ and zero otherwise, and $\delta_{c}$ is the parameter corresponding to the indicator function $I_{c}$. Table 2 presents the results of the logistic regression when all the data is used. Six models were estimated under this specification, and differ depending in the included control variables. For instance, Model (1) includes only our interest variable, a constant term, and the seven country dummy variables, while Model (4) additionally includes VIX and STOCK. Models (5) and (6) are identical to Model

\footnotetext{
${ }^{5}$ By eliminating CDS from the estimations we were also able to increase the sample period, because these indicator is available only from 2003 on for most of the countries, and in some cases we found many missing values.

${ }^{6}$ As a robustness check we also used a probit cdf but, as expected, our results remained the same.

${ }^{7}$ We also used runned regressions separately for each country. In all of the cases the sign of the parameter of interest was negative, as expected. However, statistical significance was not attained in all cases.
} 
(4), except that instead of using STOCK as a control, they use two different instruments for this variable: its first lag $(\operatorname{STOCK}(-1))$, and its return $(\mathrm{D}(\operatorname{Ln}(\mathrm{STOCK}))$. Note that in all six models the coefficient corresponding to our variable of interest resulted negative and statistically significant at conventional levels. Important to note, the magnitude of the coefficient in all the models is very similar, around -0.06. Thus, we find evidence of momentum in exchange rate for our sample of emerging market economies. Even though none of the control variables included in the different models resulted statistically significant, their signs were the expected ones; and additionally, all six models were globally significant according to likelihood ratio tests. Finally, Hong Kong and Mexico seem to present lower momentum with respect to Brazil (the base category).

\begin{tabular}{|c|c|c|c|c|c|c|}
\hline Variables & (1) & (2) & (3) & (4) & (5) & (6) \\
\hline$z$ & $\begin{array}{c}-0.0601^{\star *} \\
(0.028)\end{array}$ & $\begin{array}{c}-0.0607^{\star \star} \\
(0.028)\end{array}$ & $\begin{array}{c}-0.0601^{\star *} \\
(0.028)\end{array}$ & $\begin{array}{c}-0.0608^{\star \star} \\
(0.028)\end{array}$ & $\begin{array}{c}-0.0598^{\star \star} \\
(0.028)\end{array}$ & $\begin{array}{c}-0.0614^{\star \star} \\
(0.029)\end{array}$ \\
\hline VIX & & & $\begin{array}{l}0.0011 \\
(0.001)\end{array}$ & $\begin{array}{l}0.0010 \\
(0.001)\end{array}$ & $\begin{array}{l}0.0011 \\
(0.001)\end{array}$ & $\begin{array}{l}0.0011 \\
(0.001)\end{array}$ \\
\hline STOCK & & $\begin{array}{l}-0.0156 \\
(0.021)\end{array}$ & & $\begin{array}{c}-0.0142 \\
(0.021)\end{array}$ & & \\
\hline STOCK (-1) & & & & & $\begin{array}{c}-0.0214 \\
(0.021)\end{array}$ & \\
\hline $\mathrm{D}(\mathrm{Ln}(\mathrm{STOCK}))$ & & & & & & $\begin{array}{l}0.0040 \\
(0.015)\end{array}$ \\
\hline CHILE & $\begin{array}{c}-0.0524 \\
(0.056)\end{array}$ & $\begin{array}{c}-0.0943 \\
(0.080)\end{array}$ & $\begin{array}{c}-0.0524 \\
(0.056)\end{array}$ & $\begin{array}{l}-0.0905 \\
(0.080)\end{array}$ & $\begin{array}{c}-0.1083 \\
(0.080)\end{array}$ & $\begin{array}{l}-0.0509 \\
(0.056)\end{array}$ \\
\hline COLOMBIA & $\begin{array}{l}-0.0449 \\
(0.056)\end{array}$ & $\begin{array}{l}-0.0783 \\
(0.068)\end{array}$ & $\begin{array}{l}-0.0449 \\
(0.056)\end{array}$ & $\begin{array}{l}-0.0756 \\
(0.068)\end{array}$ & $\begin{array}{l}-0.0670 \\
(0.068)\end{array}$ & $\begin{array}{l}-0.0317 \\
(0.058)\end{array}$ \\
\hline HONG KONG & $\begin{array}{c}0.2406^{\star \star *} \\
(0.057)\end{array}$ & $\begin{array}{c}0.2306^{* * *} \\
(0.059)\end{array}$ & $\begin{array}{c}0.2408^{\star * \star} \\
(0.057)\end{array}$ & $\begin{array}{c}0.2317^{\star \star *} \\
(0.059)\end{array}$ & $\begin{array}{c}0.2270^{\star * *} \\
(0.059)\end{array}$ & $\begin{array}{c}0.2409^{\star \star *} \\
(0.057)\end{array}$ \\
\hline MEXICO & $\begin{array}{c}0.1522^{\star \star \star} \\
(0.056)\end{array}$ & $\begin{array}{c}0.1415^{\star *} \\
(0.058)\end{array}$ & $\begin{array}{c}0.1522^{\star \star \star} \\
(0.056)\end{array}$ & $\begin{array}{c}0.1425^{\star *} \\
(0.058)\end{array}$ & $\begin{array}{c}0.1391^{* *} \\
(0.058)\end{array}$ & $\begin{array}{c}0.1539^{* \star \star} \\
(0.056)\end{array}$ \\
\hline PERU & $\begin{array}{l}-0.0315 \\
(0.057)\end{array}$ & $\begin{array}{l}-0.0590 \\
(0.068)\end{array}$ & $\begin{array}{l}-0.0318 \\
(0.057)\end{array}$ & $\begin{array}{c}-0.0568 \\
(0.068)\end{array}$ & $\begin{array}{c}-0.0696 \\
(0.068)\end{array}$ & $\begin{array}{l}-0.0319 \\
(0.057)\end{array}$ \\
\hline SOUTH AFRICA & $\begin{array}{l}-0.0038 \\
(0.056)\end{array}$ & $\begin{array}{l}-0.0131 \\
(0.057)\end{array}$ & $\begin{array}{c}-0.0038 \\
(0.056)\end{array}$ & $\begin{array}{l}-0.0122 \\
(0.057)\end{array}$ & $\begin{array}{l}-0.0165 \\
(0.057)\end{array}$ & $\begin{array}{l}-0.0038 \\
(0.056)\end{array}$ \\
\hline TURKEY & $\begin{array}{l}0.0175 \\
(0.056)\end{array}$ & $\begin{array}{l}0.0251 \\
(0.057)\end{array}$ & $\begin{array}{l}0.0175 \\
(0.056)\end{array}$ & $\begin{array}{l}0.0254 \\
(0.057)\end{array}$ & $\begin{array}{l}0.0175 \\
(0.057)\end{array}$ & $\begin{array}{l}0.0319 \\
(0.057)\end{array}$ \\
\hline Constant & $\begin{array}{l}0.0117 \\
(0.042) \\
\end{array}$ & $\begin{array}{l}0.1727 \\
(0.224) \\
\end{array}$ & $\begin{array}{l}-0.0127 \\
(0.052) \\
\end{array}$ & $\begin{array}{l}0.1356 \\
(0.230) \\
\end{array}$ & $\begin{array}{l}0.2078 \\
(0.226) \\
\end{array}$ & $\begin{array}{l}-0.0126 \\
(0.052) \\
\end{array}$ \\
\hline Observations & 20,118 & 19,907 & 20,118 & 19,907 & 19,899 & 19,698 \\
\hline LL nule & -13944 & -13798 & -13944 & -13798 & -13792 & -13653 \\
\hline LL model & -13919 & -13772 & -13919 & -13772 & -13767 & -13628 \\
\hline DF & 8 & 9 & 9 & 10 & 10 & 10 \\
\hline $\mathrm{CHI}(2)$ & 50.11 & 50.92 & 50.75 & 51.46 & 50.05 & 49.25 \\
\hline
\end{tabular}

Tables 3 and 4 show results of the logistic regression separating by the two possible states. The sample used in the estimations reported in Table 3 includes only cases in which the exchange rate returns are positive, while the sample used in 
the estimations reported in Table 4 includes only cases in which they are negative. Worthy to note, we find an asymmetric effect of the previous behavior of the exchange rate's return on the probability of obtaining gains (losses) in the current period. Conditional on having observed an exchange rate depreciation in the current period, it is more likely to observe an additional depreciation next period. Meanwhile, there is no statistical evidence in favor of inertia during times in which the exchange rate in appreciating. However, the sign of the coefficient of the variable of interest is also negative when periods of exchange rate appreciation are considered (see Table 4).

Table 3: Logit estimations of the model using positive returns

\begin{tabular}{|c|c|c|c|c|c|c|}
\hline Variables & (1) & (2) & (3) & (4) & (5) & (6) \\
\hline$z$ & $\begin{array}{c}-0.0970^{* *} \\
(0.041)\end{array}$ & $\begin{array}{c}-0.1025^{\star *} \\
(0.041)\end{array}$ & $\begin{array}{c}-0.0994^{\star *} \\
(0.041)\end{array}$ & $\begin{array}{c}-0.1043^{\star *} \\
(0.041)\end{array}$ & $\begin{array}{c}-0.0992^{* *} \\
(0.041)\end{array}$ & $\begin{array}{r}-0.1036^{\star *} \\
(0.041)\end{array}$ \\
\hline VIX & & & $\begin{array}{c}-0.0025 \\
(0.002)\end{array}$ & $\begin{array}{r}-0.0020 \\
(0.002)\end{array}$ & $\begin{array}{r}-0.0027 \\
(0.002)\end{array}$ & $\begin{array}{r}-0.0024 \\
(0.002)\end{array}$ \\
\hline STOCK & & $\begin{array}{c}0.0799 * * * \\
(0.031)\end{array}$ & & $\begin{array}{c}0.0771^{* *} \\
(0.031)\end{array}$ & & \\
\hline STOCK (-1) & & & & & $\begin{array}{l}-0.0027 \\
(0.031)\end{array}$ & \\
\hline $\mathrm{D}(\operatorname{Ln}(\mathrm{STOCK}))$ & & & & & & $\begin{array}{r}0.0420^{*} \\
(0.022) \\
\end{array}$ \\
\hline CHILE & $\begin{array}{r}-0.1055 \\
(0.081)\end{array}$ & $\begin{array}{l}0.1070 \\
(0.115)\end{array}$ & $\begin{array}{c}-0.1066 \\
(0.081)\end{array}$ & $\begin{array}{l}0.0989 \\
(0.115)\end{array}$ & $\begin{array}{c}-0.1123 \\
(0.115)\end{array}$ & $\begin{array}{l}-0.1047 \\
(0.081)\end{array}$ \\
\hline COLOMBIA & $\begin{array}{c}-0.0989 \\
(0.081)\end{array}$ & $\begin{array}{l}0.0499 \\
(0.098)\end{array}$ & $\begin{array}{r}-0.0991 \\
(0.081)\end{array}$ & $\begin{array}{l}0.0447 \\
(0.098)\end{array}$ & $\begin{array}{r}-0.0913 \\
(0.098)\end{array}$ & $\begin{array}{r}-0.0722 \\
(0.083)\end{array}$ \\
\hline HONG KONG & $\begin{array}{l}0.0972 \\
(0.081)\end{array}$ & $\begin{array}{l}0.1463^{*} \\
(0.084)\end{array}$ & $\begin{array}{l}0.0940 \\
(0.082)\end{array}$ & $\begin{array}{l}0.1421^{*} \\
(0.084)\end{array}$ & $\begin{array}{l}0.0921 \\
(0.084)\end{array}$ & $\begin{array}{l}0.0936 \\
(0.082)\end{array}$ \\
\hline MEXICO & $\begin{array}{l}0.1291 \\
(0.081)\end{array}$ & $\begin{array}{c}0.1827^{\star *} \\
(0.083)\end{array}$ & $\begin{array}{l}0.1286 \\
(0.081)\end{array}$ & $\begin{array}{c}0.1805^{\star *} \\
(0.083)\end{array}$ & $\begin{array}{l}0.1283 \\
(0.083)\end{array}$ & $\begin{array}{l}0.1299 \\
(0.081)\end{array}$ \\
\hline PERU & $\begin{array}{l}-0.0391 \\
(0.083)\end{array}$ & $\begin{array}{l}0.1040 \\
(0.099)\end{array}$ & $\begin{array}{r}-0.0395 \\
(0.083)\end{array}$ & $\begin{array}{l}0.0987 \\
(0.099)\end{array}$ & $\begin{array}{l}-0.0444 \\
(0.098)\end{array}$ & $\begin{array}{c}-0.0353 \\
(0.083)\end{array}$ \\
\hline SOUTH AFRICA & $\begin{array}{r}-0.0141 \\
(0.081)\end{array}$ & $\begin{array}{l}0.0307 \\
(0.083)\end{array}$ & $\begin{array}{c}-0.0154 \\
(0.081)\end{array}$ & $\begin{array}{l}0.0281 \\
(0.083)\end{array}$ & $\begin{array}{r}-0.0171 \\
(0.083)\end{array}$ & $\begin{array}{l}-0.0158 \\
(0.081)\end{array}$ \\
\hline TURKEY & $\begin{array}{l}0.0500 \\
(0.082)\end{array}$ & $\begin{array}{l}0.0856 \\
(0.083)\end{array}$ & $\begin{array}{l}0.0497 \\
(0.082)\end{array}$ & $\begin{array}{l}0.0847 \\
(0.083)\end{array}$ & $\begin{array}{l}0.0632 \\
(0.083)\end{array}$ & $\begin{array}{l}0.0910 \\
(0.083)\end{array}$ \\
\hline Constant & $\begin{array}{c}0.1326^{\star *} \\
(0.061) \\
\end{array}$ & $\begin{array}{c}-0.6839^{* *} \\
(0.320) \\
\end{array}$ & $\begin{array}{c}0.1908^{* *} \\
(0.077)\end{array}$ & $\begin{array}{c}-0.6102^{*} \\
(0.328) \\
\end{array}$ & $\begin{array}{l}0.2213 \\
(0.327) \\
\end{array}$ & $\begin{array}{c}0.1890^{* *} \\
(0.077)\end{array}$ \\
\hline Observations & 9,718 & 9,600 & 9,718 & 9,600 & 9,609 & 9,497 \\
\hline LL nule & -6727 & -6645 & -6727 & -6645 & -6651 & -6573 \\
\hline LL model & -6717 & -6631 & -6716 & -6630 & -6641 & -6560 \\
\hline DF & 8 & 9 & 9 & 10 & 10 & 10 \\
\hline $\mathrm{CHI}(2)$ & 20.60 & 27.61 & 22.17 & 28.57 & 21.88 & 25.59 \\
\hline
\end{tabular}

Robust standard errors in parentheses

${ }^{* * *} \mathrm{p}<0.01,{ }^{* *} \mathrm{p}<0.05,{ }^{*} \mathrm{p}<0.1$

The observed asymmetric behavior may obey to the "fear of floating" in emerging market economies. Empirical and case studies have shown that these economies are more sensitive to exchange rate appreciation ${ }^{8}$ than depreciation and therefore

\footnotetext{
${ }^{8}$ Many emerging economies export commodities and benefit from exchange rate deprecia-
} 
central bank authorities are more inclined to intervene fx markets during periods in which exchange rate appreciation is observed (see, for instance, Levy-Yeyati and Sturzenegger (2007), and Pontines and Rajan (2010)). Central bank intervention during periods of exchange rate appreciation tends to generate short periods of currency reversion - i.e., short periods of exchange rate depreciation - which are exploited by traders who take short positions in dollars, leading to positive gains and further exchange rate depreciation for short periods of time.

\begin{tabular}{|c|c|c|c|c|c|c|}
\hline Variables & (1) & (2) & (3) & (4) & (5) & (6) \\
\hline$z$ & $\begin{array}{c}-0.0384 \\
(0.039)\end{array}$ & $\begin{array}{c}-0.0439 \\
(0.040)\end{array}$ & $\begin{array}{c}-0.0419 \\
(0.039)\end{array}$ & $\begin{array}{l}-0.0465 \\
(0.040)\end{array}$ & $\begin{array}{l}-0.0417 \\
(0.040)\end{array}$ & $\begin{array}{l}-0.0443 \\
(0.040)\end{array}$ \\
\hline VIX & & & $\begin{array}{l}0.0040^{\star} \\
(0.002)\end{array}$ & $\begin{array}{l}0.0033 \\
(0.002)\end{array}$ & $\begin{array}{c}0.0041^{\star *} \\
(0.002)\end{array}$ & $\begin{array}{l}0.0037^{\star} \\
(0.002)\end{array}$ \\
\hline STOCK & & $\begin{array}{c}-0.0974^{\star \star \star} \\
(0.030)\end{array}$ & & $\begin{array}{c}-0.0932^{\star * *} \\
(0.030)\end{array}$ & & \\
\hline STOCK $(-1)$ & & & & & $\begin{array}{l}-0.0405 \\
(0.030)\end{array}$ & \\
\hline $\mathrm{D}(\mathrm{Ln}(\mathrm{STOCK}))$ & & & & & & $\begin{array}{l}-0.0259 \\
(0.022)\end{array}$ \\
\hline CHILE & $\begin{array}{l}-0.0915 \\
(0.058)\end{array}$ & $\begin{array}{c}0.9173^{\star \star \star} \\
(0.315)\end{array}$ & $\begin{array}{c}-0.1745^{\star \star} \\
(0.072)\end{array}$ & $\begin{array}{l}0.8049^{* \star} \\
(0.323)\end{array}$ & $\begin{array}{l}0.2400 \\
(0.314)\end{array}$ & $\begin{array}{c}-0.1678^{\star \star} \\
(0.072)\end{array}$ \\
\hline COLOMBIA & $\begin{array}{l}-0.0064 \\
(0.078)\end{array}$ & $\begin{array}{c}-0.2699^{* *} \\
(0.112)\end{array}$ & $\begin{array}{l}-0.0080 \\
(0.078)\end{array}$ & $\begin{array}{c}-0.2597^{* \star} \\
(0.113)\end{array}$ & $\begin{array}{l}-0.1165 \\
(0.112)\end{array}$ & $\begin{array}{r}-0.0062 \\
(0.078)\end{array}$ \\
\hline HONG KONG & $\begin{array}{l}0.0017 \\
(0.078)\end{array}$ & $\begin{array}{c}-0.1877^{\star *} \\
(0.095)\end{array}$ & $\begin{array}{l}0.0016 \\
(0.078)\end{array}$ & $\begin{array}{c}-0.1799^{\star} \\
(0.095)\end{array}$ & $\begin{array}{l}-0.0520 \\
(0.095)\end{array}$ & $\begin{array}{l}0.0029 \\
(0.080)\end{array}$ \\
\hline MEXICO & $\begin{array}{c}0.3762^{\star \star \star} \\
(0.081)\end{array}$ & $\begin{array}{c}0.3114^{\star * *} \\
(0.083)\end{array}$ & $\begin{array}{c}0.3736^{* * *} \\
(0.081)\end{array}$ & $\begin{array}{c}0.3120^{* * *} \\
(0.083)\end{array}$ & $\begin{array}{c}0.3470^{\star \star \star} \\
(0.083)\end{array}$ & $\begin{array}{c}0.3736^{\star \star \star} \\
(0.081)\end{array}$ \\
\hline PERU & $\begin{array}{c}0.1726^{\star *} \\
(0.078)\end{array}$ & $\begin{array}{l}0.1044 \\
(0.080)\end{array}$ & $\begin{array}{c}0.1721^{* *} \\
(0.077)\end{array}$ & $\begin{array}{l}0.1070 \\
(0.080)\end{array}$ & $\begin{array}{l}0.1456^{*} \\
(0.080)\end{array}$ & $\begin{array}{c}0.1736^{\star *} \\
(0.078)\end{array}$ \\
\hline SOUTH AFRICA & $\begin{array}{c}-0.0233 \\
(0.079)\end{array}$ & $\begin{array}{c}-0.1934^{\star *} \\
(0.094)\end{array}$ & $\begin{array}{l}-0.0260 \\
(0.079)\end{array}$ & $\begin{array}{c}-0.1882^{\star *} \\
(0.094)\end{array}$ & $\begin{array}{l}-0.1005 \\
(0.096)\end{array}$ & $\begin{array}{l}-0.0233 \\
(0.079)\end{array}$ \\
\hline TURKEY & $\begin{array}{l}0.0054 \\
(0.077)\end{array}$ & $\begin{array}{l}-0.0557 \\
(0.080)\end{array}$ & $\begin{array}{l}0.0037 \\
(0.077)\end{array}$ & $\begin{array}{l}-0.0545 \\
(0.080)\end{array}$ & $\begin{array}{l}-0.0215 \\
(0.080)\end{array}$ & $\begin{array}{l}0.0036 \\
(0.077)\end{array}$ \\
\hline Constant & $\begin{array}{r}-0.0073 \\
(0.077) \\
\end{array}$ & $\begin{array}{c}-0.0254 \\
(0.078) \\
\end{array}$ & $\begin{array}{c}-0.0082 \\
(0.077) \\
\end{array}$ & $\begin{array}{r}-0.0250 \\
(0.078) \\
\end{array}$ & $\begin{array}{l}-0.0186 \\
(0.078) \\
\end{array}$ & $\begin{array}{r}-0.0151 \\
(0.078) \\
\end{array}$ \\
\hline Observations & 10,400 & 10,307 & 10,400 & 10,307 & 10,290 & 10,201 \\
\hline LL nule & -7205 & -7141 & -7205 & -7141 & -7130 & -7068 \\
\hline LL model & -7185 & -7114 & -7183 & -7113 & -7106 & -7044 \\
\hline DF & 8 & 9 & 9 & 10 & 10 & 10 \\
\hline $\mathrm{CHI}(2)$ & 41.28 & 52.70 & 44.97 & 55.14 & 46.50 & 46.47 \\
\hline
\end{tabular}

Finally, note that changes in the stock market index significantly affect the probability of changing state both during periods of exchange rate appreciation and depreciation. The sign of the coefficient associated to this variable is the expected one. For example, during periods of exchange rate depreciation, an increase in the stock market index leads to a higher probability of changing state, i.e., of observing an appreciation of the exchange rate. On the contrary, during periods of tion. 
exchange rate appreciation, an increase in the stock market index leads to a lower

probability of changing state, in other words, excerpts additional pressure towards further exchange rate appreciation.

\section{Concluding remarks}

This study proposes a new method for testing for nominal exchange rate momentum using a probabilistic approach. Our methodology has some advantages over the existing ones - which are based on the study of sample autocorrelation functions -, including the maximal use of existing data and the identification of the likelihood of effects at various exposure levels.

We illustrate our methodology estimating a binary response model using information on local currency / US dollar exchange rates of eight emerging economies (Brazil, Chile, Colombia, Hong Kong, Mexico, Peru, South Africa, and Turkey), which were selected according to the following criteria: countries for which there exist particular case studies of the effects of central bank intervention in foreign exchange markets, for which relevant information is available on a daily basis starting at the beginning of the 2000s, and which follow similar exchange rate regimes.

After controlling for important variables affecting the behavior of exchange rates in the short-run, we show evidence of exchange rate inertia; in other words, we find that exchange rate momentum is a common feature in this group of emerging economies. However, we find that the presence of momentum is asymmetric, being stronger and more statistically significant in moments of currency depreciation than in moments of appreciation. This asymmetric behavior may obey to the "fear of floating" in emerging market economies. Central bank intervention during periods of exchange rate appreciation tends to generate short periods of currency reversion - i.e., short periods of exchange rate depreciation - which are exploited by traders who take short positions in dollars, leading to positive gains and further exchange rate depreciation for short periods of time. 


\section{References}

Balvers, R. and Y. Wu (2006): "Momentum and mean reversion accross national equity markets", Journal of Empirical Finance 13, 24 - 48.

Beine, M.; J. Lahaye; S. Laurent; C.J. Neely; and, F.C. Palm (2006): "Central bank intervention and exchange rate volatility, its continuous and jump components", Federal reserve Bank of St. Louis working paper No. 2006 - 031C. http://research.stlouisfed.org/wp/2006/2006-031.pdf

Calvo, G. and C.M. Reinhart (2002): "Fear of floating", Quarterly Journal of Economics 117, 379 - 408.

Canales-Kriljenko, J.I. (2003): "Foreign exchange intervention in developing and transition economies: results of a survey", IMF working paper No. 03/95. http://www.imf.org/external/pubs/cat/longres.cfm?sk=16514.0

Chiang, T. and C. Jiang (1995): "Foreign exchange returns over short and long horizons", International Review of Economics and Finance 4, 267 - 282.

Domac, I. and A. Mendoza (2004): "Is there room for foreign exchange interventions under an inflation targeting framework? Evidence from Mexico and Turkey", World Bank Policy Research working paper No. 3288. http://papers.ssrn.com/sol3/papers.cfm?abstract_id=610332

Echavarría, J.J.; D.M. Vásquez; and, M. Villamizar (2009): "Impacto de las intervenciones cambiarias sobre el nivel y la volatilidad de la tasa de cambio en Colombia", Borradores de Economia No. 561, Banco de la Republica. http://www.banrep.gov.co/docum/ftp/borra561.pdf

Fama, E. and K. French (1988): " "Market efficiency, long-term returns, and behavioral finance, "Journal of Financial Economics 49, 283 - 306.

Gómez-González, J.E.; P. Morales; F. Pineda; and, N. Zamudio (2009): "An alternative methodology for estimating credit quality transition matrices", Journal of Risk Management in Financial Institutions 2, 353 - 364.

Gómez-González, J.E. and I.P.O. Hinojosa (2010): "Estimation of conditional time-homogeneous credit quality transition matrices", Economic Modelling 27, $89-96$. 
Guimaraes, R. and C. Karacadag (2004): "The empirics of foreign exchange intervention in emerging market economies: the cases of Mexico and Turkey", IMF working paper No. 04/123. http://repec.org/mmfc05/paper68.pdf

Jegadeesh, N. and S. Titman (2001): "Profitability of momentum strategies: an evaluation of alternative explanations", Journal of Finance 56, 699 - 720.

LeBaron, B. (1999): "Technical trading rule profitability and foreign exchange intervention", Journal of International Economics 49, 125 - 214.

Levich, R. (1989): "Is the foreign exchange market efficient?", Oxford Review of Economic Policy 5, 40 - 60.

Levy-Yeyati, E.L. and F. Sturzenegger (2007): "Fear of floating in reverse: exchange rate policy in the 2000s," mimeo.

Malkiel, B.G. (2003): "The efficient market hypothesis and its critics", Journal of Economic Perspectives 17, 59 - 82.

Marsh, I.W. (2000): "High-frequency Markov switching models in the foreign exchange market",Journal of Forecasting 19, 123 -134.

Meese, R. and K. Rogoff (1983): "Empirical exchange rate models of the 70s: do they fit out of sample?", Journal of International Economics 14, 3 - 24.

Michello, F.A. and S.S.H Chowdhury (2009): "Momentum strategies: evidence from the Indian stock market", mimeo.

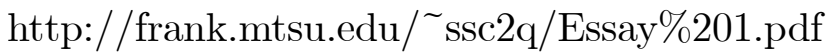

Neely, C.J. (1997): "Technical analysis in the foreign exchange market: a layman's guide", Federal Reserve Bank of St. Louis Review 79, 23 - 38.

Neely, C.J. (2001): "The practice of central bank intervention: looking under the hood", The Regional Economist, Federal Reserve Bank of St. Louis, 1 - 10.

Okunev, J. and D. White (2003): "Do momentum-based strategies still work in foreign currency markets?", Journal of Financial and Quantitative Analysis 38, $425-447$. 
Pavlova, I. and A. M. Parhizgari (2008): "International momentum strategies:a genetic algorithm approach", mimeo. http://69.175.2.130/ finman/Reno/Papers/InternationalMomentumStrategiesGAApproach.pdf Pontines, V. and R.S. Rajan (2008): "Foreign exchange market intervention and reserve accumulation in emerging Asia: is there evidence of fear of appreciation?", Economics Letters, article in press, doi:10.1016/j.econlet.2011.01.022.

Reinhart, C.M. and K. Rogoff (2004): "The modern history of exchange rate arrangements: a reinterpretation", Quarterly Journal of Economics 119, 1 - 48.

Sweeny, R. (1986): "Beating the foreign exchange market", Journal of Finance 41, $163-182$.

Tapia, M. and A. PTokman (2004): "Effects of foreign exchange intervention under public information: the Chilean case", Economia 4, 1-42.

Taylor (1992): "Efficiency in the Yen futures market at the Chicago mercantile exchange", Rational Expectations and Efficiency in Futures Markets. Routledge. Taylor, M. P. and H. Allen (1992): "The use of technical analysis in the foreign exchange market" Journal of International Money and Finance 11, 304- 314. 